\title{
THE WAY IN WHICH BIHOR COUNTY'S MOUNTAIN GUESTHOUSES ARE USING SOCIAL MEDIA TO ATTRACT CUSTOMERS
}

\author{
Naiana TुARCĂ \\ Faculty of Economics, University of Oradea, Oradea, Romania \\ ntarca@uoradea.ro
}

\begin{abstract}
The owners of the guesthouses in the mountain areas of Bihor County trying to attract guests using more and more social media channels. Their presence on social media channels plays an important role due to the fact that an increasing number of tourists are searching for information by the means of these channels. In this study, we analyzed the presence of the mountain area Bihor County guesthouses on social media channels. We also studied the way in which different social media channels are used by the owners of the guesthouses to attract guests and also the attention paid to each of them.
\end{abstract}

Keywords: online marketing, social media, touristic guesthouses

JEL classification: M31, C83

\section{Introduction}

It is well known that the number of social media users is constantly growing, both globally and in our country.

According to (Tankovska, Jan 28, 2021) in 2020 the number of social media users worldwide was more than 3.6 billion, expected to reach more than 4.41 billion in 2025.

The presence of tourist guesthouses on social media channels is important because the number of tourists who inform themselves about tourist destinations using social media channels is increasing.

It has also been found that tourists are increasingly influenced by social media in choosing their tourist destination. According to (Tussyadiah and Fesenmaier, 2009) social media increasingly influence decisions on destination selection.

According to (Jorge et al. , 2020) there is a growing interest in the use of social media in the tourism industry.

According to (Dehghani and Tumar, 2015) the use of social media in service promoting activities "attract consumers' attention and address customization of their needs".

The diversity of social media channels is vast and constantly changing.

Among the multitude of available social media channels, tourist guesthouses are increasingly using social networks to attract their guests. This is because the number of people who are getting information on social networks about tourist destinations is increasing.

According to (Tankovska, Feb 9, 2021), worldwide "social networking sites are now estimated to have 3.6 billion users".

The most popular social networks worldwide are shown in Figure 1. 


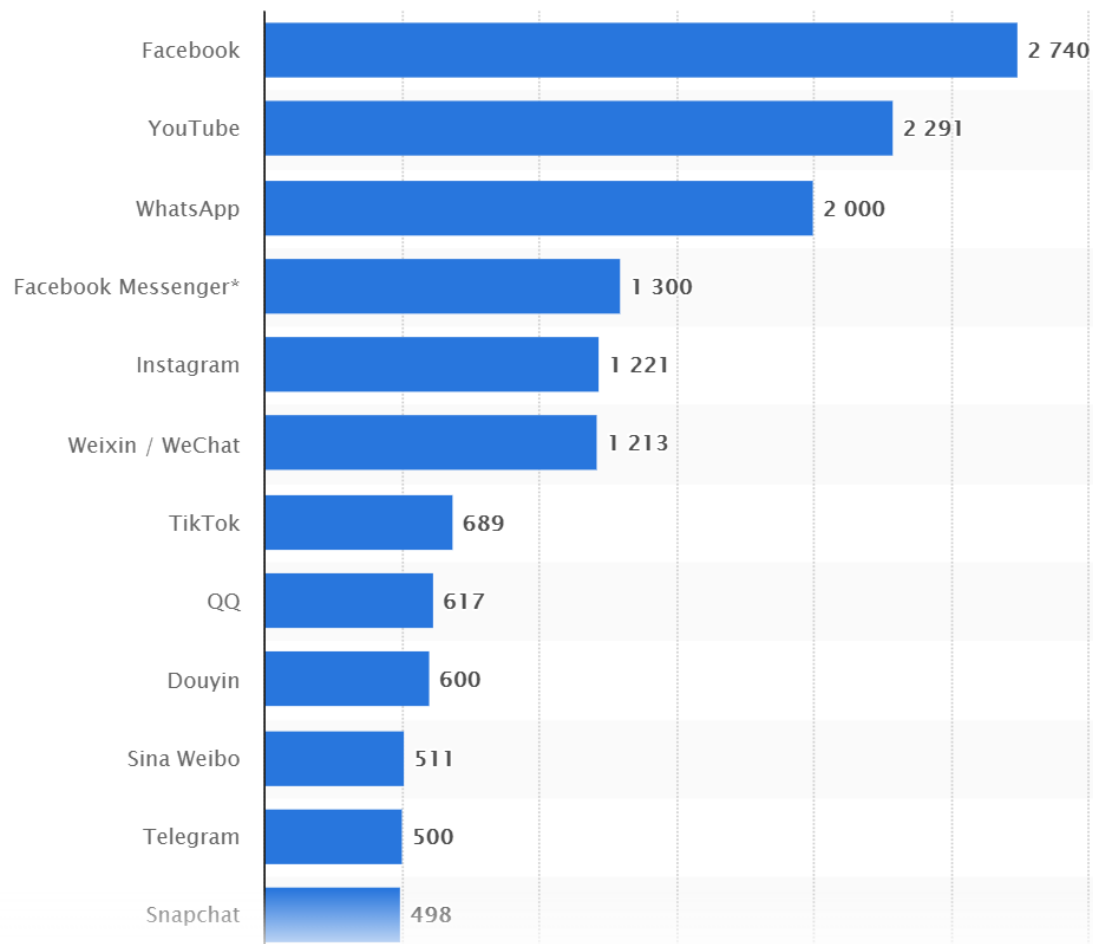

Figure 1: Most popular social networks worldwide as of January 2021, ranked by number of active users (in millions)

Source: Statista 2021, https://www.statista.com/statistics/272014/global-socialnetworks-ranked-by-number-of-users// accesed in April 2021

The rise in popularity of social media channels and the expanding use of increasingly user-friendly computer technologies have led:

- Increasing the number of tourist guesthouses that are present on social media channels;

- The increasing use of social networks by tourist guesthouses to attract guests;

- Expanding the presence of tourist guesthouses from one social network to several, so that they are visible to as many tourists as possible;

- Increase in the number of tourists who inform themselves on social media channels, and especially on social networks before choosing the destination, location for accommodation.

Also, according to (Dehghani and Tumar, 2015) social media such as Facebook act as a check on the credibility of brands.

According to (Tankovska, Feb 9, 2021) the most used social network worldwide is Facebook, which has surpassed one billion registered accounts and currently has about 2.6 billion active users each month.

Also, the most used social network in Romania is, by far, Facebook, as can be seen in Figure 2. 


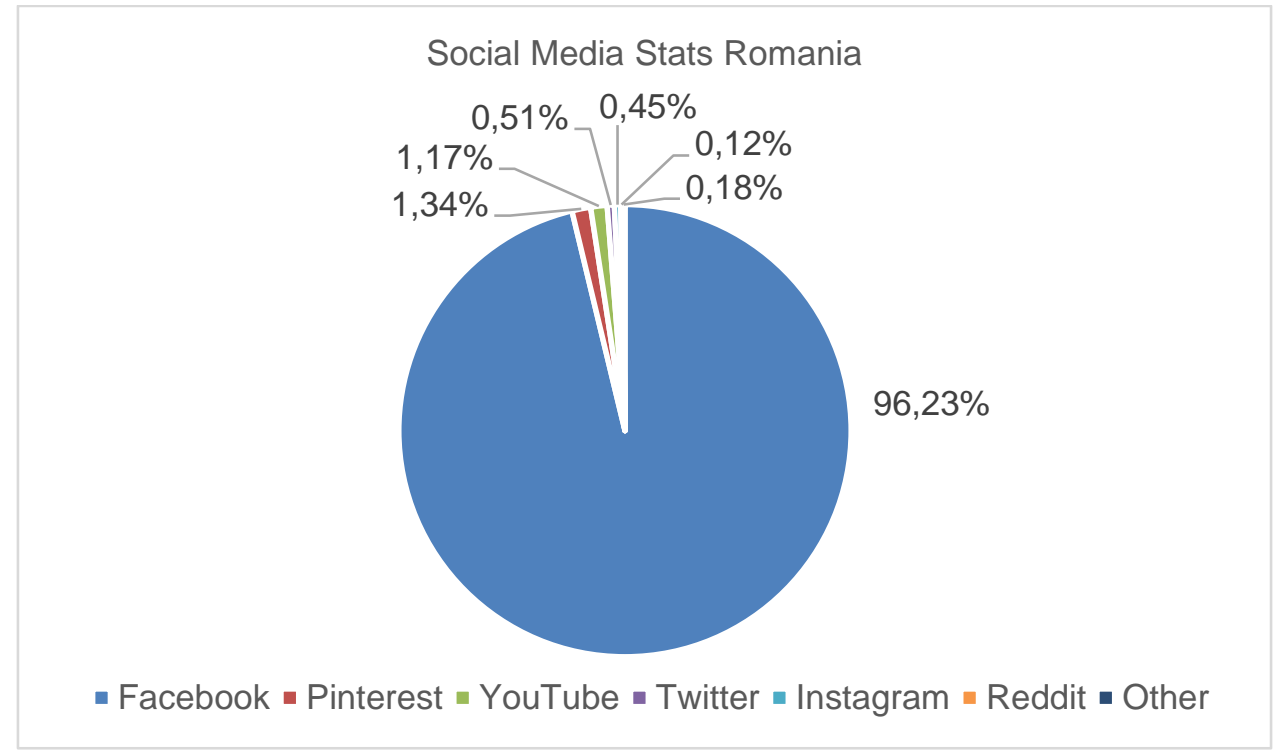

Figure 2: Social Media Stats Romania in April 2021

Source: StatCounter, Globalstats, https://gs.statcounter.com/social-mediastats/all/romania/ accessed in April 2021

\section{The premises and research methodology}

In the research we analyzed the presence of tourist guesthouses in the mountain area of Bihor County on social media channels.

The research objectives are:

- Identification of the social media channels most used by the tourist guesthouses in the mountain area of Bihor County;

- Identification of the social networks most used by the tourist guesthouses in the mountain area of Bihor County.

The research methodology consisted in analyzing the presence on social media channels of the tourist guesthouses from the mountain area of Bihor County. The data were collected from the Internet during January 2021-March 2021.

We started from the following hypotheses:

- Among the existing social media channels, tourist guesthouses use social networks the most;

- Among the existing social networks, tourist guesthouses use Facebook the most;

- Among the tourist guesthouses which are present on social networks, over $80 \%$ are present on Facebook;

- Among the tourist guesthouses which are present on social networks, less than $50 \%$ are present on social networks other than Facebook.

Research stages:

- Identification of tourist guesthouses in the mountain area of Bihor county present on social media channels;

- Identification of tourist guesthouses in the mountain area of Bihor county present on social networks; 
- Identification of tourist guesthouses in the mountain area of Bihor county that are present only on social networks, without having a website;

- Identification of the tourist guesthouses in the mountain area of Bihor county that have a web page and a link to social networks.

\section{Data analysis and interpretation}

For the research we analyzed 90 tourist guesthouses out of the total number of tourist guesthouses in the mountain area of Bihor county which are present on social media channels, (Table 1).

Table 1: Number of tourist guesthouses present on social media channels

\begin{tabular}{|l|c|}
\hline & $\begin{array}{c}\text { Number of tourist } \\
\text { guesthouses }\end{array}$ \\
\hline $\begin{array}{l}\text { Tourist guesthouses present on } \\
\text { social media channels }\end{array}$ & 90 \\
\hline $\begin{array}{l}\text { Tourist guesthouses present on } \\
\text { social networks }\end{array}$ & 90 \\
\hline $\begin{array}{l}\text { Tourist guesthouses present on other } \\
\text { social media channels }\end{array}$ & 7 \\
\hline
\end{tabular}

Out of the 90 tourist guesthouses surveyed, only $7.77 \%$ are being present on social media channels other than social networks (Figure 2). Therefore, the first hypothesis that among the existing social media channels tourist guesthouses use social networks the most is confirmed.

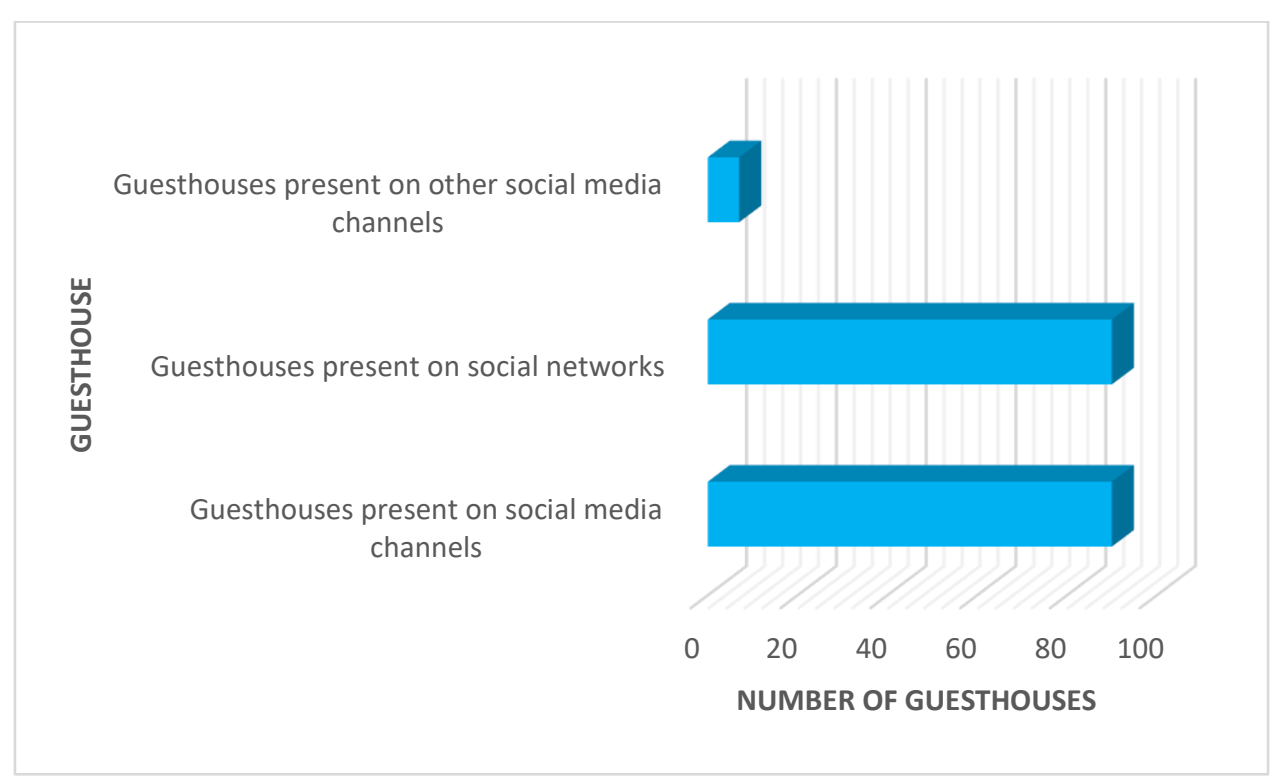

Figure 2: The presence of tourist guesthouses on social media channels 
A large number of the tourist guesthouses present on social networks, also have their own web page, from which they link to Facebook or other social networks (Table 2).

Table 2: Number of tourist guesthouses present on social networks

\begin{tabular}{|l|c|}
\hline $\begin{array}{l}\text { Tourist guesthouses present on social } \\
\text { networks }\end{array}$ & $\begin{array}{c}\text { Number of tourist } \\
\text { guesthouses }\end{array}$ \\
\hline $\begin{array}{l}\text { Tourist guesthouses that have their own } \\
\text { website with links to social networks }\end{array}$ & 90 \\
\hline $\begin{array}{l}\text { Tourist guesthouses present on } \\
\text { Facebook }\end{array}$ & 90 \\
\hline $\begin{array}{l}\text { Tourist guesthouses present on other } \\
\text { social networks }\end{array}$ & 14 \\
\hline
\end{tabular}

Of the tourist guesthouses studied, $81.11 \%$ have their own website, with links to social networks (Figure 3). Perhaps they consider that the presence on social networks could make them more visible online and bring them new customers, while retaining their existing ones.

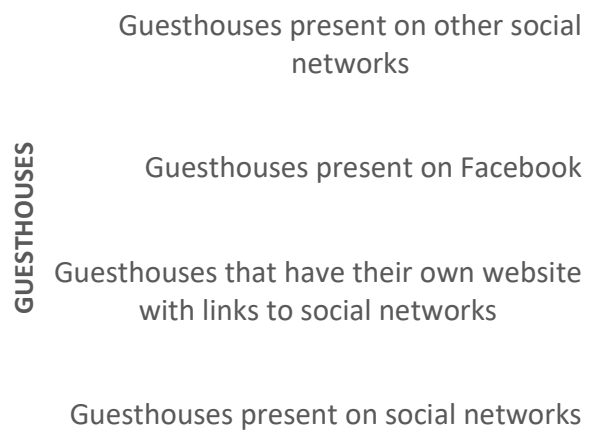

$$
\begin{array}{llllll}
0 & 20 & 40 & 60 & 80 & 100
\end{array}
$$

Figure 3: The presence of tourist guesthouses on social networks

Tourist guesthouses are primarily present on Facebook, but some of them have started to announce their presence on other social networks. Therefore, the second hypothesis that among the existing social networks, tourist guesthouses use Facebook the most is confirmed.

The tourist guesthouses analysed in the research are present on Facebook. This means that the tourist guesthouses have taken into account the fact that the most used social network in our country, is by far, Facebook. 
Of the tourist guesthouses analysed, $15.55 \%$ (Figure 3) are present on social networks other than Facebook. In the last period of time there has been a slight increase of users on social networks other than Facebook. Some of the guesthouses have noticed this and have announced their presence on these social networks as well.

Therefore, the third and fourth hypotheses, according to which more than $80 \%$ of tourist guesthouses are present on Facebook and less than $50 \%$ of tourist guesthouses are present on social networks other than Facebook, are also confirmed.

\section{Conclusion}

To attract customers, the tourist guesthouses in the Apuseni Mountains area have understood that it is very important to be accessible to as many users of the online environment as possible. Therefore, they are present, to an increasing extent, on social media channels. Social media channels can make them more visible in the online environment and can bring them new customers, respectively can make them loyal to the existing ones.

The study shows that among the existing social media channels, tourist guesthouses in the Apuseni Mountains area use social networks the most.

Tourist guesthouses, following the trend of Internet users to be primarily present on Facebook, are also primarily present on this social network.

Considering the fact that lately, people of certain age groups are migrating to other social networks, some tourist guesthouses, in order to stay in the attention of these potential customers, have started to make their presence felt on social networks other than Facebook.

\section{References:}

1. Dehghani, M., \& Tumer, M. (2015). A research on effectiveness of Facebook advertising on enhancing purchase intention of consumers. Computers in Human Behavior, 49, 597-600.

2. Jorge, F., Teixeira, M. S., Fonseca, C., Correia, R. J., \& Gonçalves, R. (2020). Social Media Usage Among Wine Tourism DMOs. In Marketing and Smart Technologies (pp. 78-87). Springer, Singapore.

3. StatCounter, Globalstats, https://gs.statcounter.com/social-mediastats/all/romania/ accessed in April 2021

4. Statista 2021, https://www.statista.com/statistics/272014/global-social-networksranked-by-number-of-users// accesed in April 2021

5. Tankovska, H. (Jan 28, 2021). Number of global social network users 20172025, Statista 2021, https://www.statista.com/statistics/278414/number-ofworldwide-social-network-users/ accesed in April 2021

6. Tankovska, H. (Feb 9, 2021). Global social networks ranked by number of users 2021, Statista 2021, https://www.statista.com/statistics/272014/global-socialnetworks-ranked-by-number-of-users/ accesed in April 2021

7. Tussyadiah, I. P., \& Fesenmaier, D. R. (2009). Mediating tourist experiences: Access to places via shared videos. Annals of Tourism Research, 36(1), 24-40 